\title{
Evaluation of Cytotoxicity and Degree of Conversion of Orthodontic Adhesives over Different Time Periods
}

\author{
Matheus Melo Pithon ${ }^{\mathrm{a}, *}$, Rogério Lacerda dos Santos ${ }^{\mathrm{a}}$, Fernanda Otaviano Martins ${ }^{\mathrm{b}}$, \\ Maria Teresa Villela Romanos , Mônica Tirre de Souza Araújo ${ }^{\mathrm{a}}$ \\ ${ }^{a}$ Department of Orthodontics, Federal University of Rio de Janeiro - UFRJ, \\ Rio de Janeiro, RJ, Brazil \\ ${ }^{\mathrm{b}}$ Department of Microbiology and Immunology, Federal University of Rio de Janeiro - UFRJ, \\ Rio de Janeiro, RJ, Brazil
}

Received: October 14, 2009; Revised: April 1, 2010

\begin{abstract}
As new orthodontic resin adhesives continue to be marketed, rapid and sensitive tests for examining their toxic effects at the 'cell and tissue level' are needed because patient safety has been identifi ed as a legal concept. The objective of the present study was to evaluate the cytotoxicity and degree of monomer conversion of orthodontic adhesives over different time periods. Seven adhesives: Transbond ${ }^{\circledR}$ XT, Transbond ${ }^{\circledR}$ Color Change, Quick Cure, EagleBond, Orthobond ${ }^{\circledR}$, Fill Mágic ${ }^{\circledR}$ and Biofix ${ }^{\circledR}$ were evaluated for their cytotoxicity in L929 fibroblastic cells and for their degree of monomer conversion over different time periods. Three control groups were also analysed: Positive control $(\mathrm{C}+)$, consisting of Tween 80 cell detergent; Negative control $(\mathrm{C}-$ ), consisting of PBS; and cell control (CC), consisting of cells exposed to any material. The dye-uptake technique that involves the absorption of a neutral red dye in viable cells was used for the cytotoxicity evaluation and the degree of conversion was evaluated using spectroscopy with infrared. The results showed the cytotoxicity of the adhesives at 24, 48, 72 and 168 hours. At these times, the viability values presented for these materials were statistically different from the groups $\mathrm{CC}$ and $\mathrm{C}-(\mathrm{p}<0.05)$. At 168 hours, all the groups showed low cytotoxicity with high cell viability and with no statistical difference with the groups $\mathrm{CC}$ and $\mathrm{C}-(\mathrm{P}>0.05)$. In the monomer conversions there was a percentage increase of monomer conversion from 24 to 72 hours. A direct correlation could be observed between cytotoxicity and monomer conversions. From this work it can be concluded that all adhesives evaluated are cytotoxic at the times of 24, 48 and 72 hours. Monomers continued conversion even after photopolymerization had stopped.
\end{abstract}

Keywords: cytotoxicity, degree of conversion, fibroblasts, dental composites

\section{Introduction}

Composite resins or dental composites today are the materials of choice to bond orthodontic accessories to dental enamel ${ }^{1,2}$. These materials have evolved considerably since the 1970's. However, there as yet no materials with ideal properties and therefore there is constant evolution and research.

Dental composites are defined as a three dimensional combination of at least two chemically different materials, with an interface that separates them both ${ }^{3}$. The resinous matrix contains a system of monomers and initiators for polymerization. The inorganic part contains glass, quartz and/or silica and the bonding agent that unites the inorganic particles with the resinous matrix. The resinous component is called the polymeric matrix ${ }^{4,5}$.

The monomer bisphenol A-Bis-glycidyl dimethacrylate (BisGMA) is the most used monomer in dentistry and is notable for its long, rigid molecule with reactive double carbon bonds at both extremities ${ }^{6}$.

One of the critical aspects of these materials is during the polymerization stage, responsible for the majority of the physical, mechanical and biological properties. Incomplete polymerization can produce a composite with high porosity, low hardness, low gloss, high capacity of staining and even cell toxicity provoked by free monomers ${ }^{7,8}$.

The quantity of double carbon bonds $(\mathrm{C}=\mathrm{C})$ present in the monomers that are converted into single bonds $(\mathrm{C}-\mathrm{C})$ to form the polymeric chain during the process of polymerization, is known as the degree of conversion'. The degree to which this conversion of reactive species occurs may affect the compatibility of the resin with the oral tissues. Therefore, a reduction in remaining double bonds to the lowest possible level is considered a desirable feature of polymerization system.

A spectrometer is the most precise way to determined the quantity of residual monomers and evaluate the degree of conversion of composites nowadays ${ }^{10}$.

Based on this premise the aim of this present article was to evaluate the effect of time on the cytotoxicity and degree of conversion after polymerization of different adhesives used in dentistry.

\section{Materials and Methods}

\subsection{Cytotoxity assay}

\subsubsection{Cell culture}

The cell line used for this study was mouse L929 fibroblasts obtained from the American Type Culture Collection (TCC, Rockville, MD) and cultivated in Eagle's minimum essential medium (MEM) (Cultilab, Campinas, São Paulo, Brazil). The cell culture was 
supplemented with $2 \mathrm{mM}$ of L-glutamine (Sigma, St. Louis, Missouri, USA), $50 \mu \mathrm{g} \cdot \mathrm{ml}^{-1}$ of gentamicin (Schering Plough, Kenilworth, New Jersey, USA), $2.5 \mu \mathrm{g} . \mathrm{ml}^{-1}$ of fungizone (Bristol-Myers-Squib, New York, USA), $0.25 \mathrm{mM}$ of sodium bicarbonate solution (Merck, Darmstadt, Germany), 10 mM of HEPES (Sigma, St. Louis, Missouri, USA), and $10 \%$ of foetal bovine serum (FBS) (Cultilab, Campinas, São Paulo, Brazil), and kept at $37{ }^{\circ} \mathrm{C}$ in a $5 \% \mathrm{CO}_{2}$ environment.

\subsubsection{Adhesives evaluated}

Seven adhesives were evaluated. Table 1 shows the manufacturer, composition, presentation and lots.

\subsection{Test sample preparation}

For the preparation and standardization of the test samples, $5 \mathrm{~mm}$ diameter and $2 \mathrm{~mm}$ thick stainless steel bipartite matrices were used (Figure 1).

The metallic matrix was placed on a glass slide and the adhesives were settled in using a plastic spatula. Having filled the matrix, a new glass slide was placed on top for subsequently photo-activation of the materials. To standardize the force of the slide on the adhesives a weight of $300 \mathrm{~g}$ was placed on the glass slide.

Photopolymerization lasted 40 seconds. The photopolymerization apparatus was fixed on a rod so the distance between the light and the specimens remained constant. The apparatus used was a Radii (SDI, Victoria, Australia) with a lamp intensity of $1400 \mathrm{mw} . \mathrm{cm}^{-2}$, calibrated with a radiometer (Demetron, Danburry, CT, USA).

After the photopolymerization the test samples were removed from the matrixes and some were immerged in a culture for post cytotoxic evaluation $(n=30)$ and the others were for degree of monomer conversion evaluation $(\mathrm{n}=5)$.

\subsection{Controls}

To verify the cell response to extreme situations, three other groups were included in the study: Group CC (cell control), consisting of cells not exposed to any material; Group $\mathrm{C}+$ (positive control), consisting of Tween 80 (Polioxietileno-20-Sorbitan); and Group C(negative control), consisting of PBS solution (Phosphate-buffered saline) in contact with the cells.

\subsection{Assessing the cytotoxity of the materials}

The materials were previously sterilized by exposing them to ultra-violet light (Labconco, Kansas, Missouri, USA) for 1 hour. Next, thirty samples of each material $(n=30)$ were placed in 24-wells plates containing Eagles' MEM (Cultilab, Campinas, São Paulo, Brazil). The culture medium was replaced with fresh medium every 24 hours, and the supernatants were collected after 1, 2, 3 and 7 days for toxicity analysis to L929 cells. The supernatants were placed in a 96-well plate containing a single layer of L929 cells and then incubated at $37{ }^{\circ} \mathrm{C}$ for 24 hours in a $5 \% \mathrm{CO}_{2}$ environment. After the incubation period, cell viability was determined using the "dye-uptake" technique described by Neyndorff et al. ${ }^{11}$ (1990), which was slightly modified. After the 24-hour incubation period, $100 \mu \mathrm{l}$ of $0.01 \%$ neutral-red staining solution (Sigma, St. Louis, Missouri, USA) was added to the medium in each well of the plates, and these were incubated for 3 hours at $37^{\circ} \mathrm{C}$ to allow the dye to penetrate into

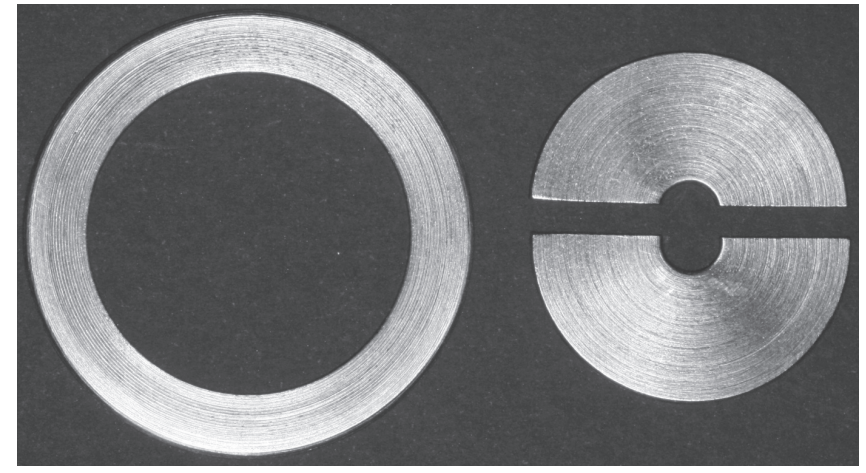

Figure 1. Stainless steel bipartite matrices.

Table 1. Materials tested with their respective manufacturers, composition and manufacturing lot.

\begin{tabular}{|c|c|c|c|}
\hline Materials tested & Manufacture & Composition & Lot \\
\hline Transbond $^{\circledR}$ XT & $\begin{array}{l}3 \mathrm{M}^{\circledR} \text { Unitek, } \\
\text { Morovia, USA }\end{array}$ & $\begin{array}{l}\text { Bis-GMA (BisphenolA Glycidyl Methacrylate), Bis-EMA (bisphenol- } \\
\text { A-ethoxylate dimethacrylate), micro quartz (load/weight) and } \\
\text { camphorquinone. }\end{array}$ & 7BU/8EX \\
\hline $\begin{array}{l}\text { Transbond }^{\circledR} \\
\text { Color Change }\end{array}$ & $\begin{array}{l}3 \mathrm{M}^{\circledR} \text { Unitek, } \\
\text { Morovia, USA }\end{array}$ & $\begin{array}{l}\text { Bis-GMA (BisphenolA Glycidyl Methacrylate), Bis-EMA (bisphenol- } \\
\text { A-ethoxylate dimethacrylate), micro quartz (load/weight) and } \\
\text { camphorquinone. }\end{array}$ & $8 \mathrm{UX} / 9 \mathrm{EX}$ \\
\hline Quick-Cure $^{\circledR}$ & $\begin{array}{l}\text { Reliance, } \\
\text { Itasca, USA }\end{array}$ & $\begin{array}{l}\text { Bis-GMA (Bisphenol A Glycidyl Methacrylate), micro-quartz (load/ } \\
\text { weight) and camphorquinone. }\end{array}$ & 707154 \\
\hline Eagle Bond $^{\circledR}$ & $\begin{array}{l}\text { American Orthodontic }{ }^{\circledR} \\
\text { Sheboygon, USA }\end{array}$ & $\begin{array}{l}\text { Bis-GMA (BisphenolA Glycidyl Methacrylate), Bis-EMA (bisphenol- } \\
\text { A-ethoxylate dimethacrylate), micro quartz (load/ weight) and } \\
\text { camphorquinone. }\end{array}$ & A8623 \\
\hline Orthobond ${ }^{\circledR}$ & $\begin{array}{l}\text { Morelli }^{\circledR} \\
\text { Sorocaba, Brazil }\end{array}$ & $\begin{array}{l}\text { BIS-GMA-dimethacrylate Glycerolate Bisphenol A, TEG-DMA- } \\
\text { dimethacrylate Triethylene glycol,HEMA-2-hydroxyl ethyl methacrylate, } \\
\text { Canforquinona, Butylated hydroxytoluene, dimethylolpropionic acid, } \\
\text { dimethylaminobenzoate, Diphenyliodoniun Hexafluotophosphate, } \\
\text { Dimethyl Amino Ethyl Methacrylate and Silicon Dioxide }\end{array}$ & 1134722 \\
\hline $\begin{array}{l}\text { Fill Magic }^{\circledR} \\
\text { Ortodôntico }\end{array}$ & $\begin{array}{l}\text { Vigodent }^{\circledR} \text {, } \\
\text { Rio de Janeiro, Brazil }\end{array}$ & $\begin{array}{l}\text { Bis-GMA Tartaric acid ester. Methacrylic Fluorine silicate glass (load) } \\
\text { and fluorine silicate glass }\end{array}$ & 001/08 \\
\hline Biofix $^{\circledR}$ & $\begin{array}{l}\text { Biodinâmica }^{\circledR}, \\
\text { Ibiporã, Brazil }\end{array}$ & $\begin{array}{l}\text { Bisphenol glicidilmetacrilato }(34.78 \%) \text {, urethane dimethacrylate } \\
\text { Ethylene; load Petroleum (41.52\%); Dioxide Titanium, Sodium Fluoride } \\
\text { and Catalyst. }\end{array}$ & 05407 \\
\hline
\end{tabular}


the living cells. After this period, the cells were fixed using $100 \mu \mathrm{l}$ of $4 \%$ formaldehyde solution (Reagen, Rio de Janeiro, Brazil)) in PBS (130 mM NaCl; $2 \mathrm{mM} \mathrm{KCl} ; 6 \mathrm{mM} \mathrm{Na} \mathrm{HPO}_{4} 2 \mathrm{H}_{2} \mathrm{O} ; 1 \mathrm{mM} \mathrm{K} \mathrm{HPO}_{4}$, $\mathrm{pH}=7.2$ ) for 5 minutes. Next, $100 \mu \mathrm{l}$ of $1 \%$ acetic acid solution (Vetec, Rio de Janeiro, Brazil) with 50\% methanol (Reagen, Rio de Janeiro, Brazil) was added to the medium to remove the dye. Absorption was measured after 20 minutes by using a spectrophotometer (BioTek, Winooski, Vermont, USA) at a wave length of $492 \mathrm{~nm}$.

\subsection{Conversion degree analysis}

After polymerization the test samples $(n=5)$ were ground to obtain the ionomer powder, that was forthwith mixed with potassium bromide $(\mathrm{KBr})$, in a ratio of $1 / 20$. This powder was placed in a tablet-maker under an approximate pressure of $8 \mathrm{t}$. An FT-IR spectrophotometer (Bomen-modelo MB-102, Quebec, Canadá) carried out the infrared spectrum measurements using the Fourier transformation method (FTIR), to determine the percentage degree of monomer conversion (DC\%) in the polymer.

The following equation was used for this study (Equation 1):

$$
\begin{aligned}
& \text { Area of band } \mathrm{C}=\mathrm{C} \text { (polymer) } \\
& \begin{aligned}
D C=1-\frac{\text { Area of band } \mathrm{C}=\mathrm{O} \text { (polymer) } \mathrm{x} 100}{\text { Area of band } \mathrm{C}=\mathrm{C} \text { (monomer) }} \\
\text { Area of band } \mathrm{C}=\mathrm{C} \text { (monomer) }
\end{aligned}
\end{aligned}
$$

In the double aliphatic carbon-carbon bond $(\mathrm{C}=\mathrm{C}$ aliphatic) the infrared absorption characteristics are around $1638 \mathrm{~cm}^{-1}$, while the double carbon-oxygen bond $(\mathrm{C}=\mathrm{O})$ has an absorption value at $1720 \mathrm{~cm}^{-1}$.

\subsection{Statistical analysis}

Statistical analyses were performed by using Statistical Package for the Social Sciences version 13.0 program (SPSS Inc, Chicago, Ilinois, U.S.A) and means and standard deviations were calculated for descriptive statistical analysis. The values for the amount of viable cells and degree of conversion were submitted to analysis of variance (ANOVA) to determine whether statistical differences existed between the groups and Tukey's test was applied thereafter.

\section{Results}

The cytotoxity results of the materials evaluated are shown in Table 2.

The degree of conversion values among the adhesives evaluated are shown in Table 3.

\section{Discussion}

This work evaluated the cytotoxicity and the degree of conversion of eight adhesives for dental use and the influence of the time factor on these questions.

After 24 hours all the experimental materials were cytotoxic with less cytotoxicity shown by Eagle Bond followed by Fill Mágic ${ }^{\circledR}$, Orthobond $^{\circledR}$ and Quick Cure. On the other hand Transbond ${ }^{\circledR}$ XT, Transbond ${ }^{\circledR}$ Color Change and Biofix ${ }^{\circledR}$ were the most cytotoxic, not presenting differences among them for this evaluation time. The values obtained for the degree of conversion proved exactly what was observed on testing for cytotoxicity. These values agree with those

\begin{tabular}{|c|c|c|c|c|c|c|c|c|c|c|c|c|}
\hline \multirow[b]{2}{*}{ Groups } & \multicolumn{3}{|c|}{24 hours } & \multicolumn{3}{|c|}{48 hours } & \multicolumn{3}{|c|}{72 hours } & \multicolumn{3}{|c|}{168 hours } \\
\hline & Mean (SD) & VB/Cel. & St* & Mean (SD) & VB/Cel. & $\mathrm{St}^{*}$ & Mean (SD) & VB/Cel. & $\mathrm{St}^{*}$ & Mean (D.P) & VB/Cel. & $\mathrm{St}^{*}$ \\
\hline Transbond XT & $99.44(31.16)$ & 12.67 & A & $846.66(132.4)$ & 71.15 & A & $466.77(32.2)$ & 75.17 & A & $901.55(166.84)$ & 84.89 & $\mathrm{ABD}$ \\
\hline $\begin{array}{l}\text { Transbond Color } \\
\text { Change }\end{array}$ & $104.44(46.12)$ & 13.31 & $\mathrm{AB}$ & $550.2(118.2)$ & 46.24 & B & $336.22(114.89)$ & 54.14 & $\mathrm{~B}$ & $913.33(91.59)$ & 86 & $\mathrm{ABD}$ \\
\hline Quick Cure & $164.44(37.74)$ & 20.95 & B & $576.6(107.9)$ & 48.46 & $\mathrm{BC}$ & $376.55(41.04)$ & 60.64 & $\mathrm{AB}$ & $855.55(127.35)$ & 80.56 & $\mathrm{ABD}$ \\
\hline Eagle Bond & $365.88(51.14)$ & 46.61 & $\mathrm{C}$ & $922(107.23)$ & 77.48 & A & $493.77(149.91)$ & 79.51 & A & $1041.33(80.76)$ & 98.05 & $\mathrm{BD}$ \\
\hline Orthobond & $165(54.30)$ & 21.02 & $\mathrm{BF}$ & $829(93.15)$ & 69.66 & A & $444.66(45.79)$ & 71.6 & $\mathrm{AB}$ & $937.33(181.20)$ & 88.26 & $\mathrm{ABD}$ \\
\hline Fill Mágic & $245.88(36.26)$ & 31.32 & $\mathrm{D}$ & 619.11(117.8) & 52.03 & $\mathrm{BD}$ & $326.77(75.80)$ & 52.62 & B & $775.88(78.24)$ & 73.06 & $\mathrm{ABD}$ \\
\hline Biofix & $122.66(50.86)$ & 15.63 & $\mathrm{AF}$ & $722.7(131.5)$ & 60.74 & $\mathrm{ACD}$ & $409.66(83.63)$ & 65.97 & $\mathrm{AB}$ & $882.33(99.92)$ & 83.08 & $\mathrm{AD}$ \\
\hline $\mathrm{C}+$ & $72.66(7.36)$ & 9.25 & A & $224.66(21.37)$ & 18.88 & $\mathrm{E}$ & $165.66(3.90)$ & 26.68 & $\mathrm{C}$ & $287.66(9.09)$ & 27.09 & $\mathrm{C}$ \\
\hline $\mathrm{C}-$ & $782.44(40.50)$ & 99.67 & $\mathrm{E}$ & $1189.6(56.7)$ & 99.97 & $\mathrm{~F}$ & $619.33(63.72)$ & 99.73 & $\mathrm{D}$ & $1052(97.97)$ & 99.06 & $\mathrm{D}$ \\
\hline $\mathrm{CC}$ & 785.33(41.77) & 100 & $\mathrm{E}$ & $1190(119.14)$ & 100 & $\mathrm{~F}$ & $621.66(62.27)$ & 100 & D & $1062(53.26)$ & 100 & D \\
\hline
\end{tabular}

Table 2. Average values of cells, standard deviation, cell viability and statistic analysis of the groups studied.

Mean = mean values for the amount of viable cells; $\mathrm{SD}=$ Standard Deviation; St* = Same letters mean no statistical difference. VB/Cel.= cell viability $(\%)$.

\begin{tabular}{|c|c|c|c|c|c|c|c|c|}
\hline \multirow{2}{*}{ Groups } & \multicolumn{2}{|c|}{24 hours } & \multicolumn{2}{|c|}{48 hours } & \multicolumn{2}{|c|}{72 hours } & \multicolumn{2}{|c|}{168 hours } \\
\hline & Mean/SD & $\mathrm{St}^{*}$ & Mean/SD & $\mathrm{St}^{*}$ & Mean/SD & $\mathrm{St}^{*}$ & Mean/SD & $\mathrm{St}^{*}$ \\
\hline Transbond XT & $43 \pm 3$ & A & $45 \pm 2$ & A & $46 \pm 1$ & A & $45 \pm 7$ & A \\
\hline Transbond Color Change & $45 \pm 2$ & A & $47 \pm 8$ & A & $47 \pm 6$ & A & $47 \pm 1$ & A \\
\hline Quick Cure & $48 \pm 2$ & $\mathrm{~B}$ & $51 \pm 3$ & $\mathrm{~B}$ & $51 \pm 4$ & $\mathrm{~B}$ & $51 \pm 2$ & B \\
\hline Eagle Bond & $69 \pm 2$ & $\mathrm{C}$ & $71 \pm 5$ & $\mathrm{C}$ & $71 \pm 5$ & $\mathrm{C}$ & $70 \pm 3$ & $\mathrm{C}$ \\
\hline Orthobond & $50 \pm 1$ & B & $52 \pm 1$ & B & $53 \pm 2$ & B & $53 \pm 5$ & B \\
\hline Fill Mágic & $60 \pm 2$ & $\mathrm{D}$ & $61 \pm 9$ & D & $61 \pm 7$ & D & $62 \pm 2$ & $\mathrm{D}$ \\
\hline Biofix & $44 \pm 2$ & $\mathrm{~A}$ & $46 \pm 4$ & A & $47 \pm 8$ & A & $47 \pm 1$ & A \\
\hline
\end{tabular}

Table 3. Average values and standard deviation of the degree of conversion of the materials tested at the times of $24,48,72$ and 168 hours $(n=5)$.

Mean $=$ mean values for the amount of viable cells; $\mathrm{SD}=$ Standard Deviation; $\mathrm{St} *$ = Same letters mean no statistical difference. 
found by Jagdish et al. ${ }^{12}$ and Jonke et al. ${ }^{13}$ when tested Transbond ${ }^{\circledR}$ XT as their cytotoxicity and degree of conversion of monomers.

After 48 hours post-polymerization Transbond ${ }^{\circledR}$ XT that at 24 hours was one of the more cytotoxic materials demonstrated less cytotoxicity showing more favorable results and closer to the Eagle Bond and Orthobond ${ }^{\circledR}$ composites that remained the least cytotoxic, when compared with the other materials. Reduction of cytotoxicity of Transbond ${ }^{\circledR}$ with the times after photopolymerization was also seen by Jagdish et al. ${ }^{12}$.

Even presenting statistical differences from the cell and negative controls, at 48 hours, there was a reduction in cytotoxicity of all adhesives. The same result was seen with the monomer conversions of these materials. At 72 hours the cytotoxicity reduction process continued, however the materials still showed cytotoxicity when compared to the controls. The same occurred with the monomer conversion. At 168 hours all materials were from a technical point of view considered biocompatible, since they didn't present any statistical difference between them and the cell and negative controls, where the cells were not exposed to any material and exposed to a PBS solution, respectively.

The degree of conversion evaluated at 168 hours did not show any large differences with those evaluated at 72 hours, in other words at 168 hours the non-converted monomers were maintained with no post-polymerization conversion as opposed to what occurred at 48 and 72 hours.

The differences found in the cytotoxic and conversion values obtained for the different adhesives evaluated could be attributed to the variation of their compositions, in terms of monomeric systems, concentration of diluents, type and quantity of load particles and initiator concentrations.

Some authors also agree that cytotoxicity of composite materials is dependent on the release of substances (unbound/free monomers and leachable components released due to degradation or erosion over time ${ }^{14}$ ) which is a function of their formulation ${ }^{15}$.

It should be pointed out that the quantity of initiators and monomers, as well as the size of the inorganic particles present in the composition of the dental adhesives were not supplied by the manufacturers, which limited the relationship of the results obtained. Another limiting point of the evaluation made was not carrying out a cytotoxic evaluation on the primer of the bonding systems used. It is important to remember that these primers are nothing more than adhesive without the inorganic load; therefore the evaluation together with the adhesives would make the results of what really takes place when bonding is carried out clinically more reliable.

In order to understand the results of cytotoxicity, the degree of monomer conversion of the adhesives was evaluated together.

Different methods can be used to check the degree of conversion of polymeric materials: differential thermal analysis (DTA), magnetic resonance, determination of magnetic resistances and spectroscopy with infrared.

Spectroscopy with infrared is the most frequently used method to measure the degree of compression since it is capable of quantifying the non reactive groups of methacrylates in the material ${ }^{16}$ directly. Consequently this method was chosen for the tests to be carried out in this work.

As carried out by Wan et al. ${ }^{17}$, the adhesive disks were ground and transformed into disks again with potassium bromide (KBr). The proportion or weight of the adhesive/KBr mixture used was 1:20. Potassium bromide is a very pure salt and is mixed with the materials since it is inert to infrared (transparent to infrared); it doesn't introduce any line on the spectrum of the sample.

The main monomeric component of the dental adhesives used here was Bis-GMA. The chemical formula of bisphenol-glycidyl-methacrylate
(Bis-GMA) has two aromatic rings - a double aliphatic carbon-carbon bond (open chain) and an aromatic bond. Therefore the analytical peak of $1638 \mathrm{~cm}^{-1}$ of the double aliphatic bond and the standard internal peak, the one that does not change during the reaction, of $1608 \mathrm{~cm}^{-1}$ of the double bonds present in the aromatic ring, were used, as carried out in previous works ${ }^{18,19}$.

The values of the monomer conversion presented corroborate those in the cytotoxicity tests, showing the importance of residual monomers in cell viability ${ }^{20}$.

A spectrometer is the most precise way to determined the quantity of residual monomers and evaluate the degree of conversion of composites nowadays ${ }^{10}$.

The study detected potential toxic effects in orthodontic adhesives, which warrants further in vivo testing. To reduce the potential cytotoxic effects, several precautionary measures can be followed. The clinician should use only as much material as necessary, and care should be taken to remove excess polymerized adhesives, particularly in areas where the adhesives may come in intimate contact with the subgingival and interproximal tissues. Excess initiators material has to be removed thoroughly by washing the tooth with a water spray once the adhesive has set. When sealants are applied, they should be painted conservatively and localized to the tooth surface where the bracket is to be placed, avoiding gingival contact wherever possible.

As it has been reported that sealants have low abrasion resistance and are removed from tooth surfaces easily by tooth brushing, their potential for demineralization prevention assumes less significance when one considers the toxicity ${ }^{20,21}$. Although in clinical situations, the volume of liquids passing through the oral cavity, including saliva, water, beverages, and so forth, might dilute the leached components and thus reduce their concentration, the prolonged exposure of tissues and organs to such noxious materials must not be overlooked. Therefore, further studies on the long term effects of low concentrations of these materials need to be investigated to verify their safety.

From this work it can be concluded that: at the times of 24, 48 and 72 hours all materials presented cellular cytotoxicity, at the 168 hours evaluation the materials were biocompatible, there is a direct relation between the degree of conversion and the cytotoxicity presented by the materials.

\section{References}

1. Bishara SE, Ajlouni R, Soliman MM, Oonsombat C, Laffoon JF and Warren J. Evaluation of a new nano-filled restorative material for bonding orthodontic brackets. World Journal of Orthodontics (Carol Stream) 2007; $8(1): 8-12$.

2. Paschos E, Kleinschrodt T, Clementino-Luedemann T, Huth KC, Hickel $\mathrm{R}$, Kunzelmann $\mathrm{KH}$, et al. Effect of different bonding agents on prevention of enamel demineralization around orthodontic brackets. American Journal of Orthodontics and Dentofacial Orthopedics (Saint Louis), 2009; 135(5):603-612.

3. Bryant RW. Direct posterior composite resin restorations: a review. Australian Dental Journal (North Sydney) 1992; 37(2):81-87.

4. Garoushi SK, Lassila LV and Vallittu PK. Direct composite resin restoration of an anterior tooth effect of fiber-reinforced composite substructure. European journal of prosthodontics and restorative dentistry (Ramford) 2007; 16(2):61-66.

5. Maeda Y, Kinoshita Y, Satho H and Yang TC. Influence of bonded composite resin cingulum rest seats on abutment tooth periodontal tissues a longitudinal prospective study. International Journal of Prosthodontics (Lombard), 2008; 21(1):37-39.

6. Peutzfeldt A. Resins composites in dentistry the monomer systems. European Journal of Oral Sciences (Copenhagem), 1997; 105(2):97-116. 
7. Yap AU, Lee HK and Sabapathy R. Release of methacrylic acid from dental composites. Dental Materials (Kidlinton), 2000;16(3):172-179.

8. Frentzen M, Foll V and Braun A. Photopolymerization of composite resin using LED technology. Journal Oral Laser Applications (Berlin) 2001; 1(3):189-194.

9. Nomoto R, Uchida K and Hirasawa T. Effect of light intensity on polymerization of light-cured composite resins. Dental Materials Journal (Tokyo), 1994; 13(2):198-205.

10. Atal M, Watts DC and Atal Z. Sinkage strain-rates of dental resin-monomer and composite systems. Biomaterials (Surrey) 2005; 6:5015-5020.

11. Neyndorff HC, Bartel DL, Tufaro F and Levy, JG. Development of a model to demonstrate photosensitizer-mediated viral inactivation in blood. Transfusion (Paris), 1990; 30:485-490.

12. Jagdisha N, Padmanabhanb S, Chitharanjanc AB, Revathid J, Palanie G, Sambasivamf $\mathrm{M}$ et al. Cytotoxicity and degree of conversion of orthodontic adhesives. Angle Orthodontist (Appleton), 2009; 79:1133-1138.

13. Jonke E, Franz A, Freudenthaler J, Konig F, Bantleon HP and Schedle A. Cytotoxicity and shear bond strength of four orthodontic adhesive systems. European Journal of Orthodontics (Oxford), 2008; 30:495-502.

14. Goldberg M. In vitro and in vivo studies on the toxicity of dental resin components a review. Clinical Oral Investigations (Berlin) 2008; 12(1):1-8.
15. Brackett MG, Bouillaguet S, Lockwood PE, Rotenberg S, Lewis JB, Messer RL, et al. In vitro cytotoxicity of dental composites based on new and traditional polymerization chemistries. Journal Biomed Materials Research B (Hoboken) 2007; 81(2):397-402.

16. Franz A, Konig F, Lucas T, Watts DC and Schedle A. Cytotoxic effects of dental bonding substances as a function of degree of conversion. Dental Materials (Kidlinton) 2009; 25(2):232-239.

17. Wan AC, Yap AU and Hastings GW. Acid-base complex reactions in resinmodified and conventional glass ionomer cements. Journal Biomedical Materials Research (Hoboken), 1999; 48(5):700-704.

18. Cunha LG, Alonso RC, Neves AC, Goes MF de, Ferracane JL and Sinhoreti MA. Degree of conversion and contraction stress development of a resin composite irradiated using halogen and LED at two C-factor levels. Operative Dendistry (Washington, DC) 2009; 34(1):24-31.

19. Shin DH and Rawls HR. Degree of conversion and color stability of the light curing resin with new photoinitiator systems. Dental Materials (Kidlinton), 2009; 25(8):1030-1038.

20. Ceen RF and Gwinnett AJ. Microscopic evaluation of the thickness of sealants used in orthodontic bonding. American Journal Orthodontics (Saint Louis) 1980; 78(6):623-629.

21. Terhune WF, Sydiskis RJ and Davidson WM. In vitro cytotoxicity of orthodontic bonding materials. American Journal Orthodontics (Saint Louis), 1983; 83:501-506. 